\title{
Erratum to: Historic Preservation: Preserving Value?
}

\author{
Martin D. Heintzelman • Jason J. Altieri
}

Published online: 23 November 2011

(C) Springer Science+Business Media, LLC 2011

\section{Erratum to: J Real Estate Finan Econ DOI 10.1007/s11146-011-9338-8}

As published, the authors are listed as Martin D. Heintzelman and Jason A. Altieri. The authors should be listed as Martin D. Heintzelman and Jason J. Altieri as shown above.

The online version of the original article can be found at http://dx.doi.org/10.1007/s11146-011-9338-8.

M. D. Heintzelman $(\bowtie) \cdot$ J. J. Altieri

School of Business, Clarkson University, P.O. Box 5790, Potsdam, NY 13699, USA

e-mail: mheintze@clarkson.edu 